doi: 10.15503.onis2021.119.126

\title{
WPŁYW TECHNIKI PISANIA NA ZAPAMIĘTYWANIE INFORMACJI
}

\author{
Aleksandra Sanigórska \\ Instytut Psychologii \\ Uniwersytet Wrocławski \\ plac Uniwersytecki 1, 50-137 Wrocław \\ e-mail: 313124@uwr.edu.pl \\ ORCID: https://orcid.org/0000-0001-6099-3911 \\ Monika Kaźmierska \\ Instytut Psychologii \\ Uniwersytet Wrocławski \\ plac Uniwersytecki 1, 50-137 Wrocław \\ e-mail: 302876@uwr.edu.pl \\ ORICD: https://orcid.org/0000-0002-1279-2549
}

\section{Abstrakt}

Cel badania. Przedstawione badanie miało na celu sprawdzenie jakości zapamiętywania $\mathrm{w}$ zależności od zastosowanych technik pisania. Przewidywano przewagę ręcznej techniki pisania nad komputerową.

Metody badań. Przeprowadzona została analiza porównawcza grup piszących ze słuchu ręcznie oraz na klawiaturze komputera. W badaniu wzięło udział 68 osób w wieku 20-46 lat, byli to głównie pracownicy banku uczestniczący w szkoleniach firmowych. Grupy były równoliczne, a przydział do danej grupy był przypadkowy. Testowano pamięć semantyczną badanych za pomocą nagranego tekstu, który został odtworzony w ujednolicony sposób. Uwzględniono czas potrzebny na zakodowanie informacji, prosząc badanych o rozwiązanie anagramów niezwiązanych z zadaniem głównym. Poziom zapamiętanych informacji był sprawdzany za pomocą testu wiedzy, który zawierał pytania z możliwością jednokrotnego wyboru.

Wyniki badań. Analiza wykazała różnicę między grupami ze względu na ilość odpamiętanych informacji na granicy istotności statystycznej. Grupa pisząca ręcznie uzyskała wyniki wyższe niż grupa pisząca na komputerze. Nieoczekiwanie, statystyki wykazały średnio niższy wynik osób deklarujących znajomość i korzystanie z mnemotechnik, niż osób, które tego nie deklarowały.

Wnioski. Pismo ręczne angażuje pamięć wzrokowo-motoryczną. Oprócz tego ze względu na dłuższy czas potrzebny do zapisania danej frazy przetwarzanie informacji trwa dłużej i angażuje dodatkowe procesy motoryczne. Wszystko to składa się na lepsze zapamiętywanie. Zastosowanie testu swobodnego przypominania, jak miało to miejsce w niektórych przytoczonych badaniach, mogłoby uwidocznić wykazaną różnicę. 
Słowa kluczowe: pismo ręczne, pismo komputerowe, pamięć, zapamiętywanie, kodowanie informacji, mnemotechniki

\section{The effect of writing techniques on memorizing information}

\section{Abstract}

Aim of the study. This study was aimed at checking the quality of remembering in relation to the writing techniques used. Handwriting technique was predicted to be superior to the computer technique.

Method. A comparative analysis was carried out on groups listening to a text and then writing it by hand or typing on a computer keyboard. 68 people, aged 20-46, participated in the survey, mainly bank employees during their corporate training sessions. The groups were equal in number and the assignment to a given group was random. The semantic memory of the respondents was tested with a recorded text, which was played in a standardized fashion. The time needed to code the information was taken into account by asking participants to solve anagrams not related to the main task. The level of remembered information was checked with a knowledge test which included single choice questions.

Results. Analysis shows a difference between the groups with regard to the amount of remembered information on the border of statistical significance. The handwriting group achieved better results than the group typing on a computer keyboard. Unexpectedly, the statistics showed a lower average score for people declaring a knowledge of mnemonics than for people who did not declare it.

Conclusion. Handwriting engages visual-motor memory. Furthermore, due to the longer time needed to write down a phrase, the processing of information lasts longer and involves more motor processes. These components result in better remembering. The application of the free recall test, as was the case in some of the studies cited, could reveal the difference shown.

Key words: handwriting, computer writing, memory, memorizing, information encoding, mnemonics

\section{WsTĘP}

Badania dotyczące wpływu sposobu zapisywania informacji na zapamiętywanie wydają się szczególnie istotne $\mathrm{w}$ dobie postępującej cyfryzacji i stopniowego zastępowania pisma ręcznego przez zapis za pomocą klawiatury komputerów i smartfonów. Niektóre badania podkreślają zalety pisania na klawiaturze, inne pisma ręcznego, ale wyniki tychże nie są rozstrzygające. Przedmiotem zainteresowania stał się więc wpływ wszechobecnej technologii na zdolności poznawcze ludzi, szczególnie na pamięć.

Wcześniejsze badania (Maldarelli, Kahrs, Hunt, Lockman, 2015) prowadzone $\mathrm{w}$ grupie dzieci dotyczyły zapamiętywania liter podczas nauki pisania. Ustalono, że trening z wykorzystaniem pisma ręcznego był skuteczniejszy w zapamiętywaniu liter $\mathrm{w}$ porównaniu $\mathrm{z}$ treningiem $\mathrm{z}$ wykorzystaniem komputera. Zdaniem autorów wiązało się to z pozytywnym wpływem wykonywania ruchu pisania czy też odrysowywania liter na ich zapamiętywanie. 
Bazgrolenie, rysowanie i pisanie to zmienne różnicujące zapamiętywanie w eksperymencie, którego autorami są Melissa Meade, Jeffrey Wammes i Myra Fernandes (2019). Celem eksperymentu było sprawdzenie pamięci uczestników w różnych warunkach. W pierwszym warunku uczestnicy usłyszeli listę 60 słów przedstawionych w losowo wybranej kolejności. Słowa należały do jednej z trzech 20 elementowych kategorii: warzywa, meble oraz środki transportu. Każde słowo było poprzedzone komunikatem jaką czynność należy podjąć po jego usłyszeniu: bazgrolenie, rysowanie lub pisanie. $W$ drugim badaniu uczestnicy słuchali trzech nagranych 2,5-3 minutowych narracji, zawierających te same słowa co w pierwszym badaniu. Zadaniem uczestników było wyłapanie z narracji słów należących do jednej z trzech opisanych kategorii (warzywa, meble, środki transportu) a następnie zapisanie ich, rysowanie lub swobodne bazgrolenie. W obu przypadkach wykazano, że bardziej korzystny wpływ na zapamiętywanie mają pisanie i rysowanie w porównaniu do bazgrolenia. Stwierdzono, że ślady wizualne i motoryczne, które powstają gdy zapisujemy lub rysujemy jakieś słowo, ułatwiają dostęp do pamięci tego słowa.

Z kolei badania Julii Li i Karin James (2016) dowodza, że pismo odręczne ułatwia kategoryzację liter u małych dzieci. Dzieje się tak ze względu na to, że w przeciwieństwie do pisma maszynowego, pisząc ręcznie dzieci tworzyły różne wersje tej samej litery. W trakcie pisania mózg kontroluje ruch ręki, aby zapisać literę, z kolei obraz zapisanej litery jest bodźcem powodującym zmianę w układzie nerwowym i lepsze zapamiętywanie.

W innym badaniu (Waterman, Havelka, Culmer, Hill i Mon-Williams, 2014) skoncentrowano się na pamięci wzrokowo-motorycznej, odpowiedzialnej między innymi za umiejętność tworzenia i interpretowania symboli pisanych. Badania dowodza, że dzięki pamięci wzrokowo-motorycznej, motoryczne aspekty pisma ręcznego mogą być bardziej zautomatyzowane, co zmniejsza obciążenie poznawcze i uwalnia zasoby dla bardziej abstrakcyjnych procesów językowych wyższego rzędu.

Podobne badanie dotyczące znaczenia uczenia się motorycznych reprezentacji symboli dla ich późniejszego rozpoznawania wzrokowego przez dorosłych wykazało, że uczestnicy z grupy pisma ręcznego lepiej rozpoznawali nowe znaki i dłużej zachowali je w pamięci niż uczestnicy uczący się przy użyciu klawiatury (Longcamp $\mathrm{i}$ in., 2008).

Z kolei w badaniu Joël Pynte, Pierre Courrieu i Cheryl Frenck-Mestre (1991) zwrócili uwagę na inny aspekt związany z pismem. Ponieważ pisanie jest procesem stosunkowo wolnym, badacze założyli, że procesy psycholingwistyczne, mogą wyprzedzać zapis usłyszanej treści. To powoduje konieczność czasowego przechowywania materiału werbalnego w pamięci roboczej i odzyskania go przed zapisaniem. W swoim eksperymencie zajęli się ostatnimi fazami procesu pisania i zdiagnozowali trzy potencjalne etapy: przetwarzanie w pamięci werbalnej, bufor motoryczny i etap zapisu. Stwierdzono, że ten ostatni jest przesunięty w czasie. Jeśli tak, to prawdopodobnie pisanie ręczne wiąże się z bardziej złożonymi procesami wewnętrznymi, co według autorów może przyczyniać się do lepszego zapamiętywania.

Badanie Kathleen Beck (2014) ujawniło, że studenci wykonujący notatki za pomocą komputera zapisywali dużo więcej informacji, ale nie osiągnęli istotnych różnic w zadaniach dotyczących pamięci długoterminowej lub krótkotrwałej. Natomiast

Ogrody Nauk i Sztuk nR 2021 (11) 
uczniowie sporządzający notatki ręcznie osiągali wyższe wyniki w zadaniach związanych z pamięcią.

Inne badanie (Peverly i in., 2013) koncentrowało się na procesach poznawczych związanych z robieniem notatek. Autorzy udowodnili, że jedynym czynnikiem przewidującym jakość notatek była szybkość pisma ręcznego, a notatki były jedynym istotnym czynnikiem przewidującym wynik testu. Na robienie notatek przez studentów miały wpływ czynniki, takie jak: umiejętność przetwarzania informacji, posiadanie planu wykładu czy poziom uwagi. Studenci, którzy robili lepsze jakościowo notatki, osiaggali lepsze wyniki. W celu sporządzania notatek o wysokiej jakości niezbędne jest wykorzystanie dwóch nadrzędnych systemów kognitywnych: rozumienia języka i pamięci roboczej. Pamięć robocza umożliwia zapamiętywanie i uczenie się poprzez przechowywanie i interpretację informacji ze środowiska i pamięci długoterminowej (Baddeley, 2000). W trakcie sporządzania notatek niezbędne jest utrzymanie dużej ilości informacji werbalnych w pamięci roboczej do czasu ich interpretacji i zapisu (Piolat, 2005).

W studium porównawczym pisma ręcznego i pisania na klawiaturze podczas robienia notatek przez studentów (Aragón-Mendizábal, Delgado-Casas, Navarro-Guzmán, Menacho-Jiménez i Romero-Oliva, 2016) przeprowadzono analizę wpływu metod kodowania i zapisu informacji na pamięć $\mathrm{w}$ ramach poziomów przetwarzania. Ponownie komputer pozwalał na szybsze notowanie i większą ilość notatek, jednak, gdy zadanie wymagało głębszego poziomu kodowania, efektywniejsze okazało się ręczne sporządzanie notatek. Grupa pisma maszynowego uzyskała lepsze wyniki $\mathrm{w}$ zadaniach rozpoznawania, natomiast grupa pisma ręcznego miał lepszy wynik w zadaniach swobodnego przypominania.

Rola ćwiczenia pisma ręcznego w nauce mówienia dzieci chińskich (co pośrednio rozumiane jest jako zapamiętywanie słów) była testowana w przedszkolach w Hongkongu. Postawiona teza o pozytywnej korelacji zmiennych została potwierdzona (Lam i McBride, 2018). W badaniach prowadzonych przez Anne E. Cunningham i Keith E. Stanovich (1990) również potwierdzono związek między pismem ręcznym a nauką wymawiania. Uczeni porównywali umiejętność wymawiania słów, które dzieci poniżej 6 lat uczyły się przez tradycyjne pisanie, pisanie na klawiaturze komputerowej lub układanie danego słowa z rozsypanki. Jednoznacznie stwierdzono, że to ręczne zapisywanie ma największy wpływ na naukę słów.

Dotychczasowe badania w większości zajmowały się pismem w kontekście nabywania języka lub zapamiętywania liter i morfemów, w bieżącym badaniu postanowiono zweryfikować, na ile te zidentyfikowane procesy związane z pismem ręcznym i maszynowym wpływają na pamięć przy zapisywaniu dłuższych sekwencji. Założono, że podobne mechanizmy zaobserwowane u dzieci, związane $\mathrm{z}$ pamięcią wzrokowo-motoryczna, mogą ułatwiać zapamiętywanie bardziej złożonych informacji przez dorosłych. Łącząc badania dotyczące dzieci, gdzie pismo ręczne ze względu na zmienność formy i mniejszą automatyzację niż pismo maszynowe powodowało skuteczniejsze uczenie się liter, stwierdzono, że prawdopodobnie pismo ręczne jako mniej zautomatyzowane niż maszynowe może wymagać dodatkowego etapu przetwarzania, co z kolei powinno ułatwiać zapamiętywanie informacji. W przedstawionym badaniu uczestnicy zapisywali informacje nie wymagające interpretacji, a tekst 
był dyktowany z jednakową szybkością dla obu warunków. Biorąc pod uwagę, że zapis ręczny wymaga więcej czasu i wymaga większego zaangażowania pamięci werbalnej, powinno to skutkować większym zaangażowaniem pamięci roboczej i większą ilością zapamiętanych informacji. W sytuacjach, gdy pobieranie informacji wymagało niższego poziomu przetwarzania, lepiej wypadli studenci korzystający z komputera, natomiast $\mathrm{w}$ zadaniach wymagających głębszego kodowania wydajność uczniów sporządzających notatki ręcznie była wyższa, postawiono więc hipotezę, że pismo ręczne w porównaniu z pismem na klawiaturze wiąże się z większą ilością zapamiętywanych informacji.

\section{Metoda}

Osoby badane

Badaniem objęto 68 osób (46 kobiet, 22 mężczyzn) w wieku 20-46 lat. Pięćdziesiąt sześć osób to pracownicy banku uczestniczący w szkoleniach firmowych, 12 osób to studenci wrocławskich uczelni. Wszyscy uczestniczyli dobrowolnie $\mathrm{w}$ badaniu i byli polskojęzyczni. Uczestnicy zostali podzieleni na dwie równoliczne grupy: (1) tych którzy zapisywali odtwarzany tekst za pomocą klawiatury $N=34$ oraz (2) tych, którzy zapisywali tekst ręcznie $N=34$. Średni wiek w warunku pisma ręcznego wynosił $M=32,85 ; S D=7,18$, a w warunku zapisu za pomocą klawiatury $M=28,6 ; S D=7,00$. Uczestnicy deklarowali różny poziom wiedzy na temat tekstu do zapamiętania (życiorys Franza Kafki), przy czym większość, 53 osoby, nie miało żadnej wiedzy na ten temat, tylko 2 osoby oceniły, że mają dużą wiedzę. Wśród uczestników 28 osób miało wykształcenie średnie a 40 osób wykształcenie wyższe. 38 osób badanych zadeklarowało, że zna i stosuje mnemotechniki, 30 osób, że nie zna ich i nie stosuje.

\section{Materiały i aparatura}

Badania zostały przeprowadzone odpowiednio za pomocą komputerów z zainstalowanym programem Microsoft Word lub (w drugiej grupie) tradycyjnych narzędzi do pisania: kartka, długopis. Tekst, który badani mieli za zadanie zanotować, dotyczył życiorysu Franza Kafki i został przygotowany na podstawie Wikipedii. Z uwagi na zminimalizowanie szansy różnorakiej identyfikacji odbiorcy z pisarzem esej składał się z zaledwie kilkunastu nieszczegółowych zdań. Pozostałe dane uczestników, tzn.: dane osobowe (wiek, płeć), informacje na temat wykształcenia (podstawowe, średnie czy wyższe), znajomości mnemotechnik (znam i korzystam versus nie znam) oraz znajomości życiorysu Franza Kafki (na skali od 1 do 5) zebrane zostały w wersji papierowej. Zastosowano test sprawdzający ilość zapamiętanych informacji oraz anagramy własnego autorstwa. Test składał się z 22 pytań typu PRAWDA/FAŁSZ i dotyczył wprost treści zapisywanego tekstu. Anagramów było 16 i były to losowo przekształcone słowa, niezależne od treści tekstu.

\section{Procedura}

Wykonano eksperyment. Badania było przeprowadzane w kilkunastoosobowych grupach, procedura dla wszystkich grup była ujednolicona. Na początku każda osoba otrzymała na kartce instrukcję, z wyszczególnionymi częściami badania. Szczególnie istotna była informacja, iż w części właściwej podczas zapisywania ze słuchu nie 
trzeba poprawiać drobnych pomyłek czy błędów ortograficznych. Miało to zapobiec nadmiernemu koncentrowaniu się badanych na sposobie zapisu danej treści, co mogłoby opóźniać pisanie i opuszczanie przez nich innych treści, a ponieważ z założenia w eksperymencie chodziło o zweryfikowanie czy forma pisania wpływa na zapamiętywanie, wybrakowany tekst mógłby przekłamywać statystyki. Wszyscy uczestnicy otrzymali informację, że biorą udział w eksperymencie psychologicznym, jednak cel podany do wiadomości badanym brzmiał: „Badanie sprawności zapisywania treści ze słuchu w zależności od techniki pisania", tak by nie starali się specjalnie koncentrować na zapamiętywaniu. Przeprowadzana była próba dźwięku, po której rozpoczęła się część właściwa badania: pisanie ze słuchu. 34 osoby pisały na komputerze, a 34 ręcznie tekst nagrany wcześniej z uwzględnieniem prędkości pisania (ręcznego i komputerowego) przetestowanej na sędziach kompetentnych. Następnie uczestnicy badania otrzymywali anagramy do rozwiązania. Zostały one zastosowane, by wyczyścić pamięć roboczą badanych. Liczba poprawnych odpowiedzi w teście była głównym wskaźnikiem ilości zapamiętanych informacji. Tak jak tempo odczytywania tekstu, tak i ilość pytań była uprzednio testowana na sędziach w celu uniknięcia efektu sufitowego.

\section{Rezultaty}

Analiza testem W Shapiro-Wilka pokazała, że zmienna poprawnych odpowiedzi nie ma rozkładu normalnego $(\mathrm{p}<0,05)$. W celu porównania ilości zapamiętanych informacji w grupie piszącej ręcznie oraz grupie piszącej na komputerze przeprowadzono więc analizę porównawczą testem U Manna-Whitneya. Analiza wykazała różnicę między grupami ze względu na ilość odpamiętanych informacji $U=424 Z=-1,88$ na granicy istotności statystycznej dla $p=0,059$. Grupa pisząca ręcznie uzyskała wyniki wyższe $(M=16,73 ; S D=1,83)$ niż grupa pisząca na komputerze $(M=15,82 ; S D=1,83)$.

Testy wykazały istotną statystycznie różnicę $(p=0,03 ; U=402,5)$ między grupą osób deklarujących znajomość i korzystanie z mnemotechnik oraz grupy osób, które tego nie deklarowały. Osoby korzystające z mnemotechnik otrzymały jednak wyniki niższe $(M=15,8 ; S D=1,95)$ niż osoby deklarujące ich nieznajomość $(M=16,65 ; S D=$ 1,74).

Analizy ogólne nie wykazały istotnych statystycznie różnic między płciami pod względem ilości zapamiętanych informacji z zachowanym podziałem na grupy osób piszących ręcznie i na komputerze $(p>0,05)$. Wyniki kobiet $(M=16,22 ; S D=1,79)$ nieznacznie różniły się od wyników mężczyzn $(M=15,08 ; S D=1,72)$.

\section{DysKusJA}

Uzyskane wyniki potwierdzaja, że odręczne pisanie słyszanego tekstu lepiej wpływa na zapamiętywanie informacji niż pisanie na klawiaturze komputera. Analiza porównawcza testem U Manna-Whitneya pokazała, że wyniki osób piszących ręcznie były wyższe niż osób notujących komputerowo. Wynik tej analizy jednak był na granicy istotności statystycznej. Ponieważ dowiedziono wcześniej, że pismo ręczne ma znaczną przewagę nad zapisem komputerowym podczas nauki artykulacji u dzieci (Cunningham, Stanovich, 1990), można przypuszczać, że w przedstawionym badaniu przy zwiększeniu próby różnice między grupami zarysowałyby się silniej. 
W warunku pisma ręcznego angażującego pamięć wzrokowo-motoryczną proces przetwarzania trwa dłużej i angażuje dodatkowe procesy motoryczne, co powinno skutkować lepszym zapamiętywaniem. Być może zastosowanie testu swobodnego przypominania, jak miało to miejsce $\mathrm{w}$ niektórych przytoczonych badaniach, uwidoczniłoby wykazaną różnicę. Ponieważ Silvia Lam i Catherine McBride (2018) stwierdziły, że to regulacja uderzeń, wizualno-motoryczna integracja i płynność w pisaniu razem wzięte ułatwiają naukę wymawiania, można przyjąć to założenie jako wyjaśnienie roli pisania przy zapamiętywaniu, szczególnie $\mathrm{w}$ zestawieniu pisma ręcznego i komputerowego. Przeprowadzone badanie uznaje się więc za obiecujący wstęp do dalszych analiz wpływu ręcznego pisma na zapamiętywanie.

Od dawna robienie notatek jest uważane, zarówno przez wielu uczniów, jak i pedagogów, za dobrą formę utrwalania materiału. Ze względu na cyfryzację coraz częściej, szczególnie w późniejszych latach edukacji, rezygnuje się ze sporządzania notatek ręcznych na rzecz opracowania notatek elektronicznych, prawdopodobnie z powodów ergonomicznych, tzn.: programy komputerowe dają możliwość szybszego tworzenia tekstu, łatwego rozsyłania plików w różnych formatach, a także odczytywania ich. Przedstawione badanie może pozwolić na nowo zwrócić uwagę uczonych na proces utrwalania informacji we współczesnym świecie i skłonić do przemyślenia, czy warto odejść od tradycyjnego pisma.

W badaniu zaskakujący okazał się rezultat dotyczący deklarowanej przez badanych znajomości i korzystania z mnemotechnik. Zgodnie z oczekiwaniem spodziewano się, że badani deklarujący tę znajomość osiagną wyniki wyższe, analiza porównawcza jednak pokazała relację odwrotną. Osoby korzystające z mnemotechnik osiagnęły wyniki niższe niż osoby deklarujące ich nieznajomość. Prawdopodobnych przyczyn tego nieoczekiwanego rezultatu jest wiele, np. powodem tegoż mogło być złe zrozumienie przez osoby badane deklaracji korzystania z mnemotechnik. Logicznym wytłumaczeniem wydaje się być też nadmierna pewność siebie osób korzystających z takich technik, która może obniżyć koncentrację. Wreszcie, mogło wystąpić zjawisko samospełniającej się przepowiedni: w przypadku zadania pytania o mnemotechniki, osoby badane zwykle są przekonane o wysokim poziomie trudności testu, dlatego zmieniają swoje zachowanie w taki sposób, że uzyskują wynik, którego się spodziewali. Szczególnie dotyczy to uczestników znających mnemotechniki, którzy mogą czuć się szczególnie zobligowani do uzyskania dobrego wyniku. To z kolei podnosi poziom pobudzenia, który - jak wynika z prawa Yerkesa-Dodsona - może zmniejszyć efektywność wykonania zadania. Podsumowując, doprecyzowanie deklaracji o mnemotechnikach, jak i ewentualne przedłużenie badania oraz inne hipotetyczne poprawki należałoby wziąć pod uwagę przy replikacji badań.

\section{Bibliografia}

[1] Aragón-Mendizábal, E., Delgado-Casas, C., Navarro-Guzmán, J.-I., Menacho-Jiménez, I., Romero-Oliva, M.-F. (2016). A comparative study of handwriting and computer typing in note-taking by university students. Comunicar, 24 (48), 101-107.

[2] Baddeley, A. D. (2000). The episodic buffer: a new component of working memory? Trends in Cognitive Sciences, $4(11), 417-423$

[3] Beck, K. M. (2014). Note taking effectiveness in the modern classroom. The Compass. Arcadia University Scholary Journal, 1 (1). 
[4] Cunningham, A. E., Stanovich, K. E. (1990). Early spelling acquisition: writing beats the computer. Journal of Educational Psychology, 82 (1), 159-162.

[5] Lam, S. S., McBride, C. (2018). Learning to write: the role of handwriting for chinese spelling in kindergarten children. Journal of Educational Psychology. 110 (7), 917-930.

[6] Li, J. X., James, K. H. (2016). Handwriting generates variable visual output to facilitate symbol learning. Journal of Experimental Psychology, 145 (3), 298-313.

[7] Longcamp, M., Boucard, C., Gilhodes, J.-C., Anton, J.-L., Roth, M., Nazarian, B., Velay, J.-L. (2008) Learning through hand- or typewriting influences visual recognition of new graphic shapes: behavioral and functional imaging evidence. Journal of Cognitive Neuroscience, 20 (5), 802-815.

[8] Maldarelli, J. E., Kahars, A. B., Hunt, S. C., Lockman, J. J. (2015). Development of early handwriting: visual-motor control during letter copying. Developmental Psychology, 51 (7), 879-888.

[9] Meade, M. E., Wammes, J. D., Fernandes, M. A. (2019). Comparing the influence of doodling, drawing, and writing at encoding on memory. Canadian Journal of Experimental Psychology /Revue Canadienne de Psychologie Experimentale, $73(1), 28-26$.

[10] Peverly, S. T., Vekaria, P. C., Reddington, L. A., Sumowski, J. F., Johnson, K. R., Ramsay, C. M. (2013). The relationship of handwriting speed, working memory, language comprehension and outlines to lecture note-taking and testtaking among college students. Applied Cognitive Psychology, 27 (1), 115-126.

[11] Piolat, A., Olive, T., Kellogg, R. T. (2005). Cognitive effort during note taking. Applied Cognitive Psychology, 19 (3), 291-312.

[12] Pynte, J., Courrieu, P., Frenck-Mestre, Ch. (1991). Evidence of repeated access to immediate verbal memory during handwriting. European Journal of Psychology of Education, 6 (2), 121-125.

[13] Waterman, A. H., Havelka, J., Culmer, P. R., Hill, L. J. B., Mon-Williams M. (2015). The ontogeny of visual-motor memory and its importance in handwriting and reading: a developing construct. Proceedings of the Royal Society B. 282 (1798) 